\title{
The Tetraspanin KAI1/CD82 Is Expressed by Late-Lineage Oligodendrocyte Precursors and May Function to Restrict Precursor Migration and Promote Oligodendrocyte Differentiation and Myelination
}

\author{
Angeliki Mela and James E. Goldman \\ Department of Pathology and Cell Biology, Columbia University, New York, New York 10032
}

In the adult mammalian brain, oligodendrocyte progenitors can differentiate into mature oligodendrocytes during remyelination. Mechanisms that regulate migration and differentiation of progenitors are of great importance in understanding normal development and demyelinating/remyelinating conditions. In a microarray analysis comparing adult and neonatal 04-positive $(+)$ cells, we found that the tetraspanin KAI1/CD82 is far more highly expressed in adult $04^{+}$cells than in neonatal $04^{+}$cells (Lin et al., 2009). CD82 is a metastasis suppressor, and its expression is often downregulated or lost in the advanced stages of metastatic cancer. We hypothesized that CD82 could be a factor that restricts migration and promotes differentiation of maturing oligodendrocytes. Western blot analysis of isolated adult $\mathrm{O4}^{+}$cells confirms the elevated levels of $\mathrm{CD} 82$, which continues to be expressed as these become $01^{+}$in vitro. In the adult rat white matter, CD82 is coexpressed with CC1 and olig2 but not with NG2 or GFAP. Immature cells of the neonatal forebrain subventricular zone (SVZ) infected in vivo with a retrovirus that constitutively expresses CD82 do not remain immature but differentiate into either $\mathrm{CC}^{+}$and $\mathrm{MBP}^{+}$myelinating oligodendrocytes in the white matter or zebrinII ${ }^{+}$astrocytes in the cortex. Their migration from the SVZ is severely restricted. In contrast, downregulation of CD82 in SVZ cells in vivo, using retroviral-expressed short hairpin RNAs (shRNAs), prevents their differentiation into myelinating oligodendrocytes. shRNA-expressing cells remained PDGF receptor $\alpha$ positive, olig2 ${ }^{+}$, or NG2 $^{+}$or became $\mathrm{CCl}^{+}$nonmyelinating oligodendrocytes or $\mathrm{GFAP}^{+}$astrocytes. $\mathrm{CD} 82$ thus appears to be a critical molecule in the regulation of oligodendrocyte progenitor migration and myelination.

\section{Introduction}

Oligodendrocyte progenitor cells populate the mammalian brain and differentiate into oligodendrocytes during normal development. In pathological conditions in which demyelination occurs, as in multiple sclerosis, they can differentiate into myelinating oligodendrocytes during remyelination, a critical repair process (Gensert and Goldman, 1997; Mason and Goldman, 2002; Mason et al., 2004). Studies of the mechanisms that regulate progenitor survival, migration, and proliferation are of great interest toward understanding both normal development and pathological conditions and may be helpful in the search for therapeutic treatment of demyelinating diseases.

Oligodendrocyte development consists of successive stages, distinguishable on the basis of specific cell surface antigens. The O4 monoclonal antibody binds to immature oligodendrocytes at an intermediate stage between the early A2B5-positive $(+) / \mathrm{O} 4-$ negative $(-)$ glial progenitor cells and the more mature $\mathrm{O} 1^{+}$cells (Sommer and Schachner, 1981; Gard and Pfeiffer, 1990). In a

Received June 29, 2009; accepted July 28, 2009.

This work was supported by National Institutes of Health Grant NS17125.

Correspondence should be addressed to Dr. James E. Goldman, Department of Pathology, P\&S 15-420, Columbia University Medical Center, 630 West 168th Street, New York, NY 10032. E-mail: jeg5@columbia.edu. D01:10.1523/JNEUROSCI.3075-09.2009

Copyright $\odot 2009$ Society for Neuroscience $\quad$ 0270-6474/09/2911172-10\$15.00/0 microarray analysis (Lin et al., 2009), we compared the RNA levels of genes expressed in $\mathrm{O}_{4}{ }^{+}$cells isolated from the adult rat white matter with those of $\mathrm{O}_{4}{ }^{+}$cells from the neonatal rat forebrain. A number of genes involved in apoptosis, migration, and differentiation display significantly different expression levels in the adult relative to the neonatal cells.

One of the genes more highly expressed in adult $\mathrm{O}^{+}$cells is Kail/CD82, which encodes a transmembrane glycoprotein of the tetraspanin family. CD82 has not been studied in oligodendrocytes. It is best known in cancer biology, because its expression is often downregulated or lost in the advanced stages of cancer (Jackson et al., 2005; Liu and Zhang, 2006). Overexpression of CD82 inhibits cancer cell migration and invasion in vitro, suppresses metastasis, and, in some cases, induces apoptosis (Dong et al., 1995; Ono et al., 1999; Yang et al., 2001). CD82 was first identified as an accessory molecule in T-cell activation and formation of the immunological synapse, being present in both T-cells and antigen-presenting cells (Lagaudrière-Gesbert et al., 1998; Shibagaki et al., 1998, 1999). The clustering of CD82 on the plasma membrane of T-cells by a specific anti-CD82 antibody induces tyrosine phosphorylation of signaling adapter proteins, such as Vav-1 and SLP76, and rearrangement of the actin cytoskeleton through Rho GTPases (Delaguillaumie et al., 2002). As a tetraspanin, CD82 forms complexes with other tetraspanins 
and a wide range of other transmembrane proteins, such as integrins and growth factor receptors such as epidermal growth factor receptor (EGFR) and c-Met, as well as with lipid rafts (Odintsova et al., 2003; Delaguillaumie et al., 2004; Takahashi et al., 2007; Todeschini et al., 2007).

We therefore hypothesized that CD82 might the slow the migration and promote the differentiation of maturing oligodendrocyte progenitors. Our results show that CD82 is expressed in $\mathrm{O} 4{ }^{+}$cells in the adult rat brain and continues to be expressed during myelination. Its constitutive expression in neonatal subventricular zone (SVZ) cells in vivo promotes the differentiation of progenitors into myelinating oligodendrocytes and restricts their migration. In contrast, preventing the expression of CD82 with a short hairpin RNA (shRNA) strategy in vivo inhibits progenitor differentiation and myelination.

\section{Materials and Methods}

Media. Unless otherwise stated, all media reagents were purchased from Sigma. C-DMEM contained the following: DMEM (Invitrogen) with 3.7 $\mathrm{g} / \mathrm{L}$ sodium bicarbonate, $10 \%$ FBS (Invitrogen), $1 \mathrm{~mm}$ sodium pyruvate (Invitrogen), and $100 \mu \mathrm{g} / \mathrm{ml}$ penicillin/streptomycin (Invitrogen). N2B3 medium contained the following: a modified version of the N2 medium described by Bottenstein and Sato (1979), composed of DMEM-F-12 (Invitrogen), $2.4 \mathrm{~g} / \mathrm{L}$ sodium bicarbonate, $10 \mathrm{ng} / \mathrm{ml} \mathrm{D-biotin,} 5 \mu \mathrm{g} / \mathrm{ml}$ insulin, $20 \mathrm{~nm}$ progesterone, $100 \mu \mathrm{m}$ putrescine, $5 \mathrm{ng} / \mathrm{ml}$ selenium, $50 \mu \mathrm{g} / \mathrm{ml}$ transferrin, $15 \mathrm{~mm}$ HEPES, $100 \mu \mathrm{g} / \mathrm{ml}$ penicillin/streptomycin, $30 \mathrm{~nm}$ triiodothyronine, and $1 \mathrm{mg} / \mathrm{ml} \mathrm{BSA}$. O2A medium contained the following: DMEM, $2.4 \mathrm{~g} / \mathrm{L}$ sodium bicarbonate, $10 \mathrm{ng} / \mathrm{ml}$ D-biotin, $5 \mu \mathrm{g} / \mathrm{ml}$ insulin, 20 nм progesterone, $100 \mu \mathrm{M}$ putrescine, $5 \mathrm{ng} / \mathrm{ml}$ selenium, $50 \mu \mathrm{g} / \mathrm{ml}$ transferrin, $15 \mathrm{~mm}$ HEPES, $100 \mu \mathrm{g} / \mathrm{ml}$ penicillin/streptomycin, $2 \mathrm{~mm}$ glutamine,

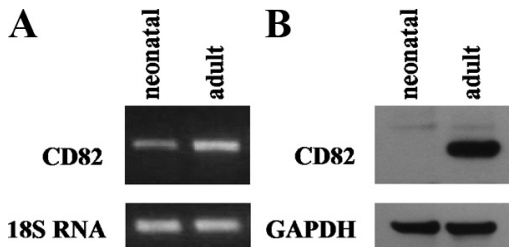

Figure 1. CD82 expression in acutely isolated $04^{+}$cells. Semiquantitative RT-PCR $(\boldsymbol{A})$ and Western blot analysis $(\boldsymbol{B})$ in $04^{+}$cells isolated from neonatal rat forebrain and adult rat white matter. 18S RNA and GAPDH were used as controls.
A

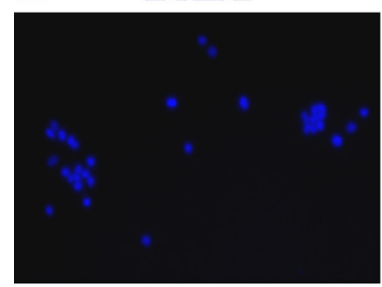

B

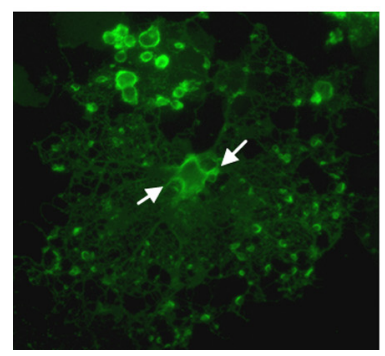

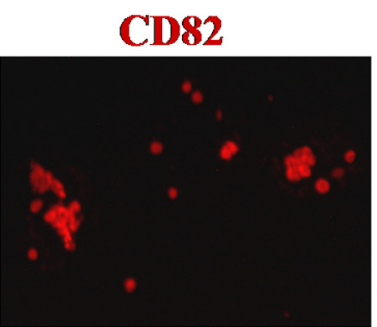

CD82

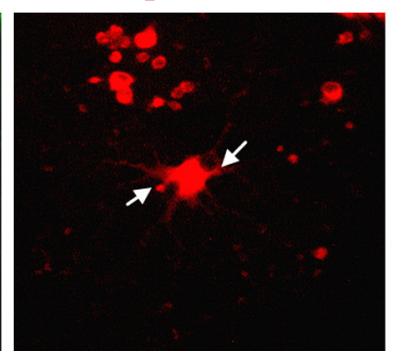

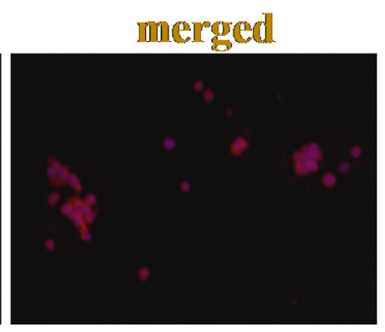

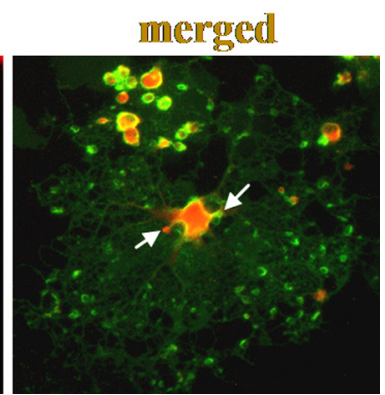

Figure 2. CD82 expression in vitro. $04^{+}$cells acutely isolated from the adult rat white matter $(\boldsymbol{A})$ and after $7 \mathrm{~d}$ in culture $(\boldsymbol{B})$. CD82 continues to be expressed as $04^{+}$cells become $01^{+}$oligodendrocytes in the cell body and processes (arrows). and $0.5 \%$ FBS. Isolation medium contained the following: $0.9 \mathrm{M}$ sucrose in $1 \times$ MEM (Invitrogen) supplemented with 20 mM HEPES, pH 7.2.

Isolation of $\mathrm{O}^{+}$cells. Sprague Dawley adult female (3 months old) and neonatal rats [postnatal day 0 (P0) to $\mathrm{P} 1$ ] were used. Neonatal forebrains (with striata and meninges removed) and adult subcortical white matter were mechanically and enzymatically dissected as described previously (Gensert and Goldman, 2001). Briefly, tissue was shredded using forceps and digested in a solution containing $0.125 \%$ trypsin (Invitrogen), 20 $\mathrm{U} / \mathrm{ml}$ papain (Roche Applied Science), and $285 \mathrm{U} / \mathrm{ml}$ DNase (Sigma) at $37^{\circ} \mathrm{C}$ in a shaking water bath for $1 \mathrm{~h}$. The cellular suspension was filtered through $70 \mu \mathrm{m}$ Nitex mesh, and an equal volume of isolation medium was added to neutralize trypsin. The cell suspension was centrifuged at $1000 \times g$ for $10 \mathrm{~min}$, and the resulting pellet was resuspended in O2A medium. $\mathrm{O}^{+}$progenitors were isolated by immunopanning to $>95 \%$ purity. Immunopan plates were prepared by incubating $60 \mathrm{~mm}$ Petri dishes overnight with goat anti-mouse IgM $(20 \mu \mathrm{g} / \mathrm{ml}$; Rockland Immunochemicals) in $50 \mathrm{~mm}$ Tris, $\mathrm{pH} 9.5$, at $37^{\circ} \mathrm{C}$. The plates were then washed three times with $\mathrm{Ca} / \mathrm{Mg}$-free (CMF)-PBS, incubated with $\mathrm{O} 4$ hybridoma supernatant (American Type Culture Collection) for at least $2 \mathrm{~h}$, and washed again three times with CMF-PBS, and the dissociated cells were incubated for $1 \mathrm{~h}$ at $37^{\circ} \mathrm{C}$. Plates were then vigorously washed with CMFPBS to remove immunonegative cells. $\mathrm{O}^{+}$cells were detached using TrypLE (Invitrogen) applied for $10 \mathrm{~min}$ at $37^{\circ} \mathrm{C}$. After deactivation of the trypsin using C-DMEM, progenitor cells were pelleted by centrifugation. All animal experiments were performed under the guidelines of the Columbia University Institutional Animal Care and Use Committee.

Cell culture and immunofluorescence staining. $\mathrm{O}^{+}$progenitors were resuspended in N2B3 medium and plated on poly-L-lysine-coated eightwell glass chamber slides (Nunc) at 2000 cells per well. N2B3 medium was changed every $2-3 \mathrm{~d}$. Cultured cells were fixed in $4 \%$ paraformaldehyde solution for $10 \mathrm{~min}$ at room temperature and stored in PBS at $4{ }^{\circ} \mathrm{C}$ until use. Cell cultures were blocked with 5\% horse serum (Sigma) for 30 min and then labeled with the following antibodies: rabbit anti-CD82 C-16 (1:80; Santa Cruz Biotechnology) and mouse IgMs O4 and O1 (1:50, hybridoma supernatants; American Type Culture Collection), overnight at $4^{\circ} \mathrm{C}$. Cells were washed three times with PBS and incubated in AlexaFluor-conjugated secondary antibodies (1:2000; Invitrogen) for $1 \mathrm{~h}$ at room temperature and then counter-stained with $4^{\prime}, 6^{\prime}$-diamidino2-phenylindole (DAPI) nuclear stain.

Semiquantitative reverse transcription-PCR. $\mathrm{O}^{+}{ }^{+}$or $\mathrm{C} 6$ cell pellets were flash frozen in liquid nitrogen and stored at $-80^{\circ} \mathrm{C}$. Total RNA was isolated using an RNeasy kit (Qiagen) and reverse-transcribed using the Thermoscript reverse transcription (RT)-PCR system for first-strand cDNA synthesis (Invitrogen). PCR using Platinum Taq (Invitrogen) was performed with the following CD82-specific primers: GCAGGCTGTGTCAAAGTCAC and GTACTTGGGGACCTTGCTGT as forward and reverse, respectively. Primers TTGACGGAAGGGCACCACCAG and GCACCACCACCCACGGAATCG were used to amplify $18 \mathrm{~S}$ RNA as a control. All primers were designed to amplify sequences that contain introns, so that spliced mRNA could be distinguished from contaminating genomic DNA and were tested for accuracy using the National Center for Biotechnology Information/Primer basic local alignment search tool.

Western blot. $\mathrm{O}^{+}{ }^{+}$or $\mathrm{C} 6$ cells were lysed using the CelLyticM Cell Lysis Reagent with Protease Inhibitor Cocktail (Sigma), and protein levels were quantified using the Bradford assay. Total protein $(10 \mu \mathrm{g})$ was separated under reducing conditions on NuPAGE $4-12 \%$ BisTris gels (Invitrogen) at $100 \mathrm{~V}$ for $90 \mathrm{~min}$ and transferred on nitrocellulose membrane. The blots were blocked using 5\% dry milk in TBS-T (Tris-buffered saline with $0.05 \%$ Triton $\mathrm{X}-100$ ) for $60 \mathrm{~min}$ at room temperature and incubated at $4^{\circ} \mathrm{C}$ overnight in $3 \%$ dry milk in 
TBS-T with rabbit anti-CD82 C-16 (1:500; Santa Cruz Biotechnology). Blots were then washed three times in TBS-T and incubated in $3 \%$ dry milk in TBS-T with HRP-conjugated secondary antibody (goat anti-mouse and goat anti-rabbit, 1:1000; Pierce Chemical) for $1 \mathrm{~h}$ at room temperature. Blots were developed using SuperSignal West Pico Chemiluminescent Substrate (Pierce Chemical). To ensure equal protein loading, the blots were reprobed using a mouse anti-glyceraldehyde-3-phosphate dehydrogenase (GAPDH) antibody (1:1000; EnCor Biotechnology).

Immunostaining procedures. Frozen tissue sections were dried, rehydrated in PBS, blocked with $5 \%$ horse serum $/ 1 \%$ Triton $\mathrm{X}-100$ in PBS, and then incubated with primary antibodies overnight at $4^{\circ} \mathrm{C}$. The sections were then washed with PBS, incubated with the appropriate AlexaFluor-conjugated secondary antibodies (1:2000; Invitrogen) for $1 \mathrm{~h}$ at room temperature, and counterstained with DAPI. The following primary antibodies were used: rabbit anti-CD82 C-16 (1:80; Santa Cruz Biotechnology), mouse anti-green fluorescent protein (GFP) (1:200; Invitrogen), rabbit antiGFAP (1:500; Dako), mouse anti-CC1 (1:50; Calbiochem), mouse anti-MBP (1:500; Covance), rabbit anti-PDGF receptor $\alpha$ (PDGFR $\alpha$ ) (1:500; kind gift from Dr. P. Canoll, Columbia University, New York, NY), mouse anti-NG2 (1: 500; kind gift from Dr. W. Stallcup, Burnham Institute, La Jolla, CA), mouse anti-zebrinII [a marker for early astrocytic development and for mature astrocytes (Staugaitis et al., 2001), 1:100; kind gift from Dr. R. Hawkes, University of Calgary, Calgary, Alberta, Canada], and guinea pig anti-olig2 (1:200; kind gift from Dr. T. Jessel, Columbia University, New York, NY).

Microscopy and cell counting. Stained sections were examined and photographed using a Carl Zeiss Axiophot 200 fluorescent microscope equipped with an Axiocam (Carl Zeiss) and OpenLab imaging software (Improvision). Micrographs were merged using Adobe Photoshop (Adobe Systems). Five representative $40 \times$ fields from three brains were photographed, and cells stained positive for each marker were manually counted.

Cloning procedures. CD82 cDNA was obtained by RT-PCR on rat mRNA using the following gene-specific primers: AgeI/CD82, CTAACCGGTATGGGGGCAGGCTG as forward; BamHI/CD82, CTAGGATCCGTACTTGGGGACCTTG as reverse. After double digestion with AgeI and BamHI, the CDNA was inserted into a modified pQCXIX-internal ribosomal entry site (IRES)-enhanced GFP (EGFP) vector (Clontech). The modified vector PQCXIX-IRES-EGFP was used for the production of control retrovirus. All enzymes used were from New England Biolabs.

Design of shRNA sequences and CD82 downregulation efficiency. Three rat CD82-specific siRNA target sequences were chosen (s1, GAGCAGCTTCATTTCCGTC; s2, TGCTAACAAGCTGAAGCAG; s3, GACGAAGGAGGAGGACAAC), and the respective complementary shRNA oligonucleotide strands were designed according to the guidelines of the Knockout RNAi Systems User Manual (PT3739-1; Clontech). The two complementary shRNA strands ( $2 \mathrm{nmol}$ of each) were annealed in buffer containing $100 \mathrm{~mm} \mathrm{CH}_{3} \mathrm{COOK}, 30$ mм HEPES, pH 7.4, and $2 \mathrm{mM}\left(\mathrm{CH}_{3} \mathrm{COO}\right)_{2} \mathrm{Mg}$ under the following conditions: $5 \mathrm{~min}$ at $95^{\circ} \mathrm{C}$, $10 \mathrm{~min}$ at $70^{\circ} \mathrm{C}$, and then sequential $5 \mathrm{~min}$ incubations at $60^{\circ} \mathrm{C}, 45^{\circ} \mathrm{C}$, $37^{\circ} \mathrm{C}$, and $25^{\circ} \mathrm{C}$. The resulting double-stranded shRNA-encoding DNA
CD82
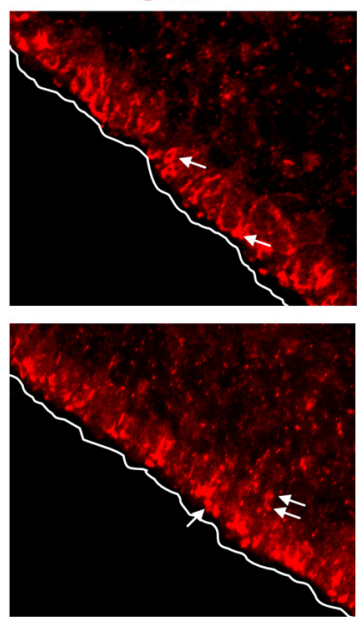

CD82
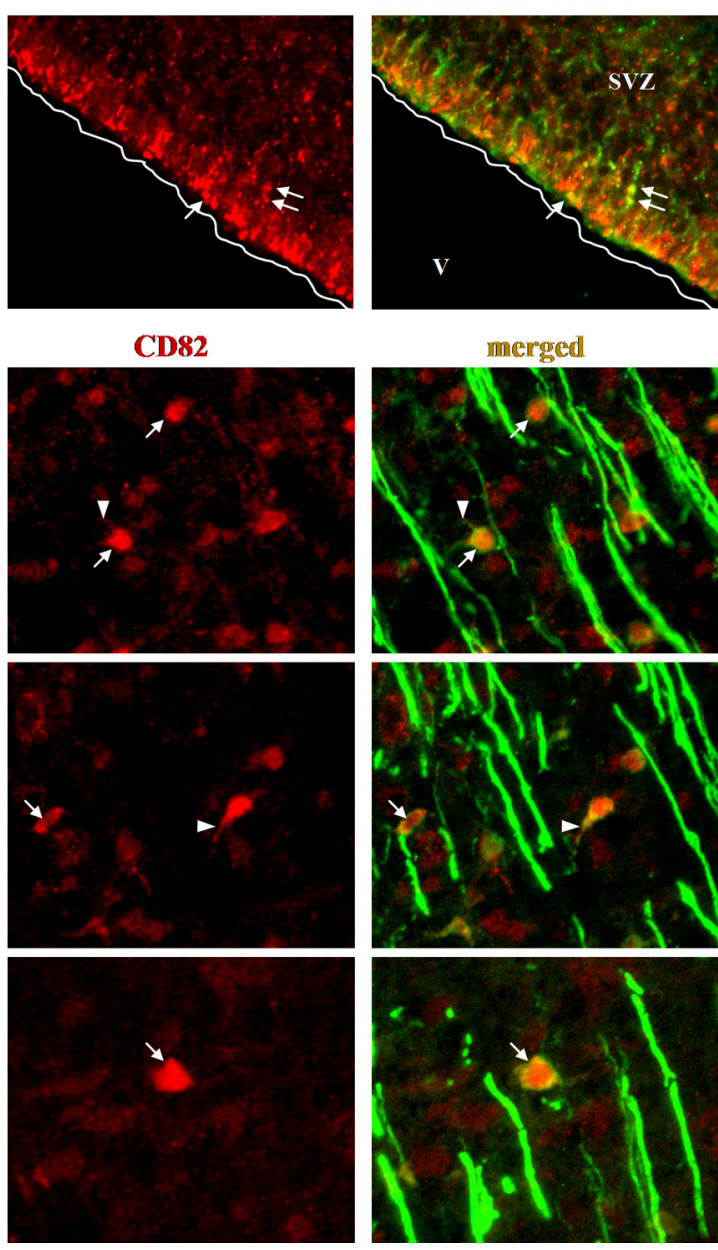
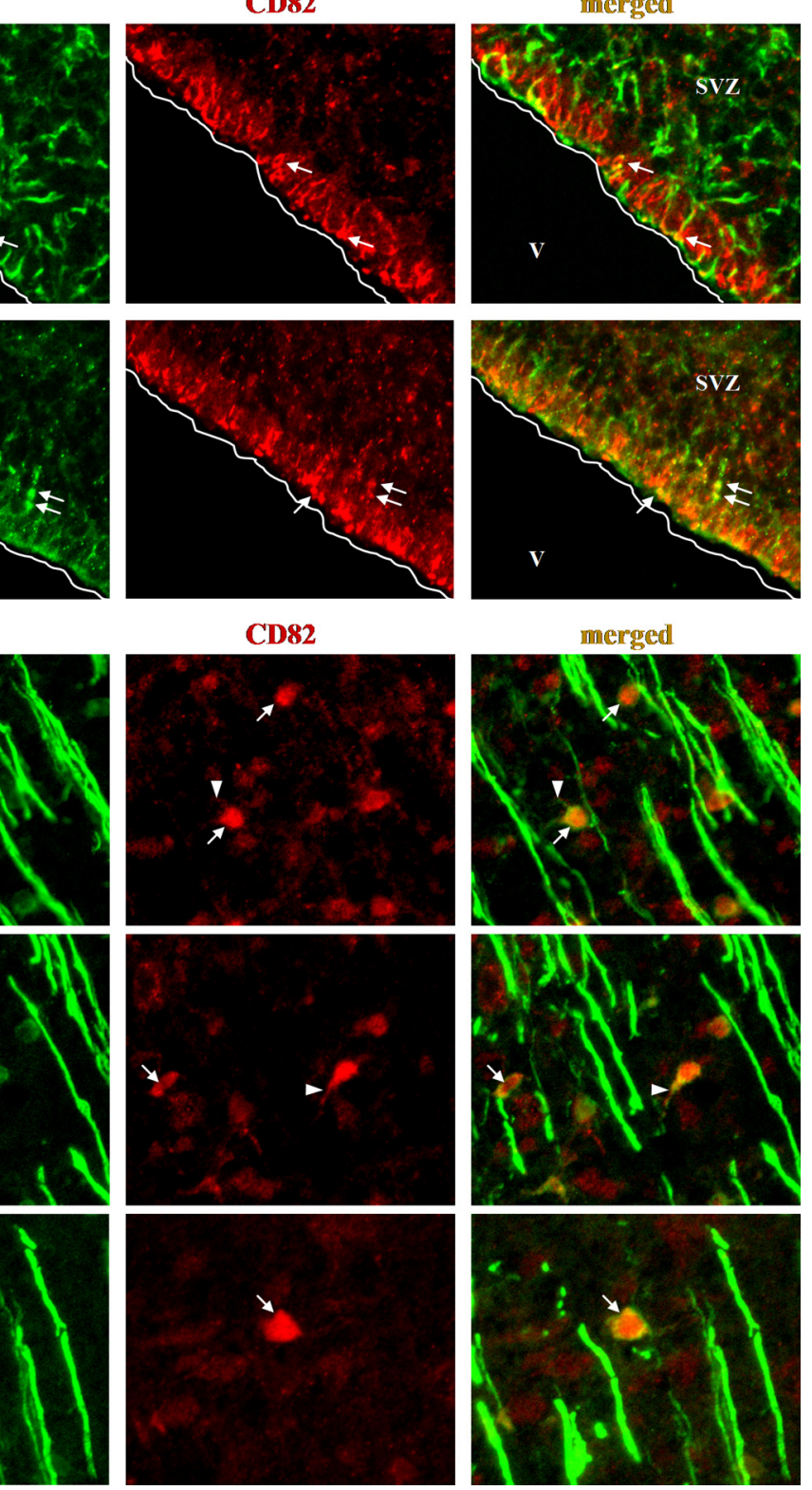

Figure 3. CD82 expression in the neonatal (P1) rat brain. $A$, Expression in nestin ${ }^{+}$and vimentin ${ }^{+}$cells of the subventricular zone (arrows). B, Examples of CD82 expression in the cell body (arrows) and the adjacent processes (arrowheads) of myelinating oligodendrocytes in the brainstem. V, Ventricle.

oligonucleotides were cloned into the pSIREN-RetroQ-ZsGreen vector (Clontech) into BamHI and EcoRI overhangs. shRNA-expressing retroviruses then were generated as described below, and C6 cells cultured in C-DMEM were infected. Three days after infection, cells were collected, resuspended in PBS/10\% BSA, and fluorescence-activated cell sorted for ZsGreen in a BD FACS ARIA system (BD Biosciences). ZsGreen-shRNA-expressing and non-expressing (control) C6 cells were replated separately and left in culture for another $3 \mathrm{~d}$ to recover. Total protein and mRNA were then isolated and analyzed for CD82 expression.

Retroviral production and stereotactic injections. To generate nonreplicating retroviruses, plasmids were cotransfected with vesicular stomatitis virus G vector into GP2 293 cells as described previously (Kakita and Goldman, 1999). Viral titers were determined in colony-forming units (CFUs) by infecting C6 cells with serial tenfold retroviral dilutions. At $48 \mathrm{~h}$ after infection, the number of the $\mathrm{GFP}^{+}$cell clusters was counted, and the CFUs were calculated by multiplying by the dilution factor. The titer of all used retroviruses was $10^{6} / \mathrm{ml}$. Two-day-old Sprague Dawley rat pups were anesthetized by immersion in an ice bath for $8 \mathrm{~min}$ and 

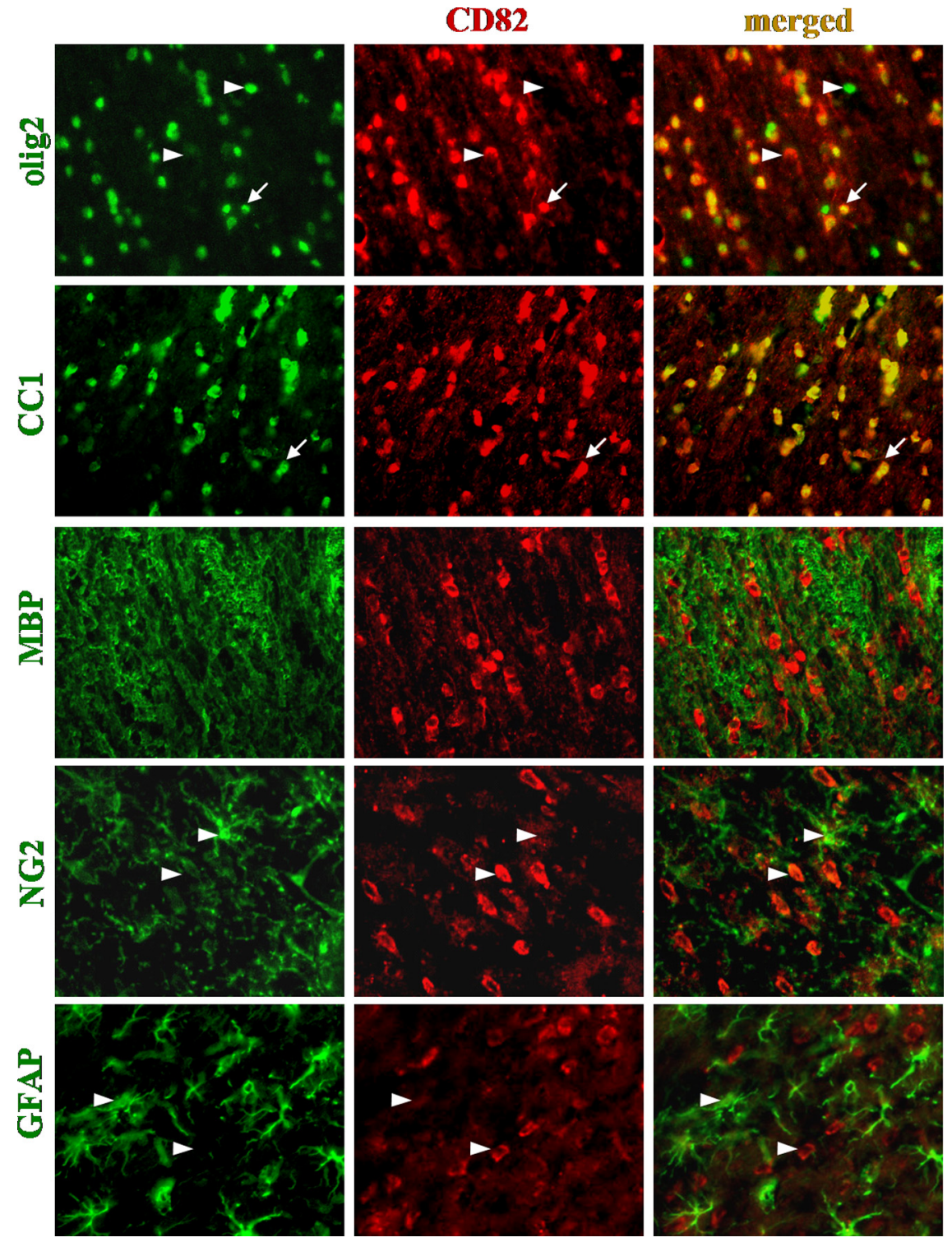

Figure 4. CD82 expression in the adult rat white matter. CD82 is expressed in $\mathrm{CC}^{+}{ }^{+}$and olig2 ${ }^{+}$oligodendrocyte lineage cells It is localized mainly in the cell body, not in the myelin sheath. CD82 is not expressed in NG2 ${ }^{+}$cells or GFAP ${ }^{+}$astrocytes. Arrows show typical examples of double-positive cells, and arrowheads show typical single-positive cells for each marker, with the exception of MBP.

positioned in a stereotactic apparatus (Stoelting). Stereotactic coordinates used for all experiments were $1.0 \mathrm{~mm}$ anterior and $2.0 \mathrm{~mm}$ lateral to bregma at a depth of $2.0 \mathrm{~mm}$. Injections were performed using a $10 \mu \mathrm{l}$ Hamilton syringe with $1 \mu \mathrm{l}$ of retrovirus at a rate of $0.2 \mu \mathrm{l} / \mathrm{min}$. Incisions were closed, and animals were allowed to recover. Four brains were analyzed per time point at 7, 30, 60, and 90 d postinjection (dpi). Animals were anesthetized with ketamine-xylazine before cardiac perfusion with PBS and 4\% paraformaldehyde. Brains were postfixed for $24-48 \mathrm{~h}$ and then transferred to PBS until use or to $30 \%$ sucrose until immersion for frozen tissue sagittal [through the rostral migratory stream (RMS)] and coronal cryosections $(12 \mu \mathrm{m})$. All animal experiments were performed according to the guidelines of the Columbia University Institutional Animal Care and Use Committee.

\section{Results}

CD82 is more highly expressed in adult than in neonatal $\mathrm{O}^{+}$cells

Using a microarray analysis (Lin et al., 2009), we compared the RNA levels of genes expressed in $\mathrm{O}^{+}{ }^{+}$cells isolated from adult rat white matter and $\mathrm{O}_{4}^{+}$cells isolated from the neonatal rat forebrain. $C D 82$ is among the genes that are far more highly expressed in adult cells (CD82 microarray fold change, 15.50). To confirm the microarray data, semiquantitative RT-PCR and Western blots were performed for CD82. First, total RNA was extracted from acutely isolated neonatal and adult $\mathrm{O}_{4}^{+}$ cells and reverse transcribed into cDNA using random oligonucleotides. Genespecific primers were then used to amplify CD82. There is a significant difference in the RNA levels that parallels the microarray results (Fig. 1). To determine whether the transcriptional differences observed by both microarray and RT-PCR correspond to protein expression differences, Western blot analysis was performed using proteins extracted from acutely isolated neonatal and adult $\mathrm{O}_{4}{ }^{+}$cells. The results confirm that protein levels are significantly higher in the adult $\mathrm{O}_{4}{ }^{+}$cells compared with neonatal cells (Fig. 1). Indeed, CD82 expression in the neonatal $\mathrm{O}^{+}{ }^{+}$cells was not detectable on the blots.

To examine whether CD82 continues to be expressed in more mature oligodendrocytes, we used an in vitro approach. Adult $\mathrm{O}^{+}$cells were isolated from rat white matter and plated in eight-well chamber slides at a density of 2000 cells per well. Some cells were allowed to settle and were fixed $1 \mathrm{~h}$ after isolation, whereas the remaining cells were allowed to differentiate in N2B3 medium for $10 \mathrm{~d}$ in culture. Most of the cells $(>80 \%)$ differentiated into $\mathrm{O}^{+}$oligodendrocytes displaying characteristic morphological features, such as expansion of the cell membrane and extension of multiple processes. After fixation, immunofluorescence was performed using anti-CD82, O1, and $\mathrm{O} 4$ antibodies. We found that CD82 is present in acutely isolated adult $\mathrm{O}^{+}$cells and continues to be expressed as they differentiate into $\mathrm{O}^{+}$oligodendrocytes. It is mainly localized in the cell body rather than in the cell processes (Fig. 2).

\section{CD82 is present in oligodendrocytes in the developing and} adult rat brain

CD82 expression has not been studied in mammalian brain. To examine where CD82 is expressed in rat brain, we performed immunofluorescence on cryosections of neonatal (P1), P10, and adult (3 months) rat brain using an anti-CD82 antibody in combination with antibodies against several cell lineage markers (olig2, NG2, CC1, MBP, GFAP, zebrinII, Tuj1, vimentin, and nestin). In the cerebral hemispheres of the neonatal rat brain, CD82 expression is very low. CD82 is undetectable in cortex, white matter, and RMS, although it is present in radial processes of cells in the SVZ that also express vimentin (Fig. 3). These have the morphology and location of the ventricular end feet of radial glia. We did not study this cellular localization further but rather 
focused on oligodendrocyte development. When we examined the brainstem of $\mathrm{P} 1$ rats, in which there is active myelination, we found CD82 ${ }^{+}$cells (Fig. 3). A number of these appear to be myelinating oligodendrocytes, because they are also $\mathrm{MBP}^{+}$. Some are connected to myelin sheaths by thin, $\mathrm{MBP}^{+}$processes (Fig. 3 ). However, CD82 does not appear in the myelin sheaths themselves but rather is restricted to cell bodies. In the P10 rat brain, CD82 expression is present in cells of the white matter and the overlying cortex (data not shown) localizing to cell bodies and not myelin. CD82 colocalizes with CC1 $189.8 \%$ of the $\mathrm{CD} 82^{+}$cells are also $\left.\mathrm{CC}^{+}\right)$and to some extent with olig2 $\left(30.36 \%\right.$ of $\mathrm{CD} 2^{+}$cells are also olig $\left.{ }^{+}\right)$. Few $\mathrm{CD}^{+} 2^{+}$cells also express NG2 $(4.8 \%)$. Cells in the RMS do not express CD82.

In the adult brain, many cells express CD82. Here, CD82 colocalizes with CC1 $\left(93 \%\right.$ of $\mathrm{CD} 2^{+}$cells are also $\left.\mathrm{CC}^{+}\right)$in both cortex and white matter (Fig. 4). Approximately one-third of the CD82 ${ }^{+}$cells coexpress olig2. Triple labeling for CD82, CC1, and olig2 showed that $95 \%$ of the $\mathrm{CD}_{2}{ }^{+}$cells are also CC1 ${ }^{+}$, whereas $37 \%$ are olig $2^{+}$. Cells that were olig ${ }^{+} / \mathrm{CC} 1^{-}$ were also $\mathrm{CD}_{82}{ }^{-}$, which indicates that CD82 and olig2 colocalization occurs in advanced stages of oligodendrocyte development. This idea is supported by our additional observation that most $\mathrm{CD} 82^{+}$ cells do not express NG2 $\left(\mathrm{CD} 82^{+} / \mathrm{NG} 2{ }^{+}\right.$ cells are $<3 \%$ of the total CD $82^{+}$population). $\mathrm{GFAP}^{+}$or zebrinII ${ }^{+}$astrocytes also do not express CD82, consistent with an expression restricted to the oligodendrocyte lineage. The extent of myelination makes it difficult to distinguish individual myelinating oligodendrocytes that are $\mathrm{CD}^{+} 2^{+} / \mathrm{MBP}^{+}$.
A

7 dpi

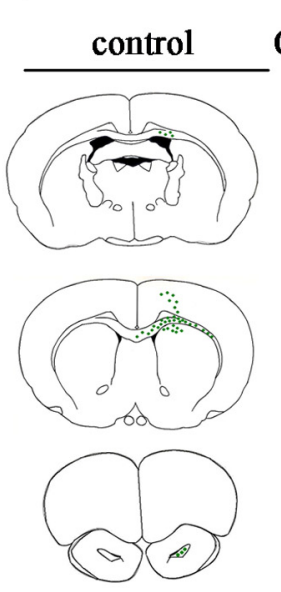

B
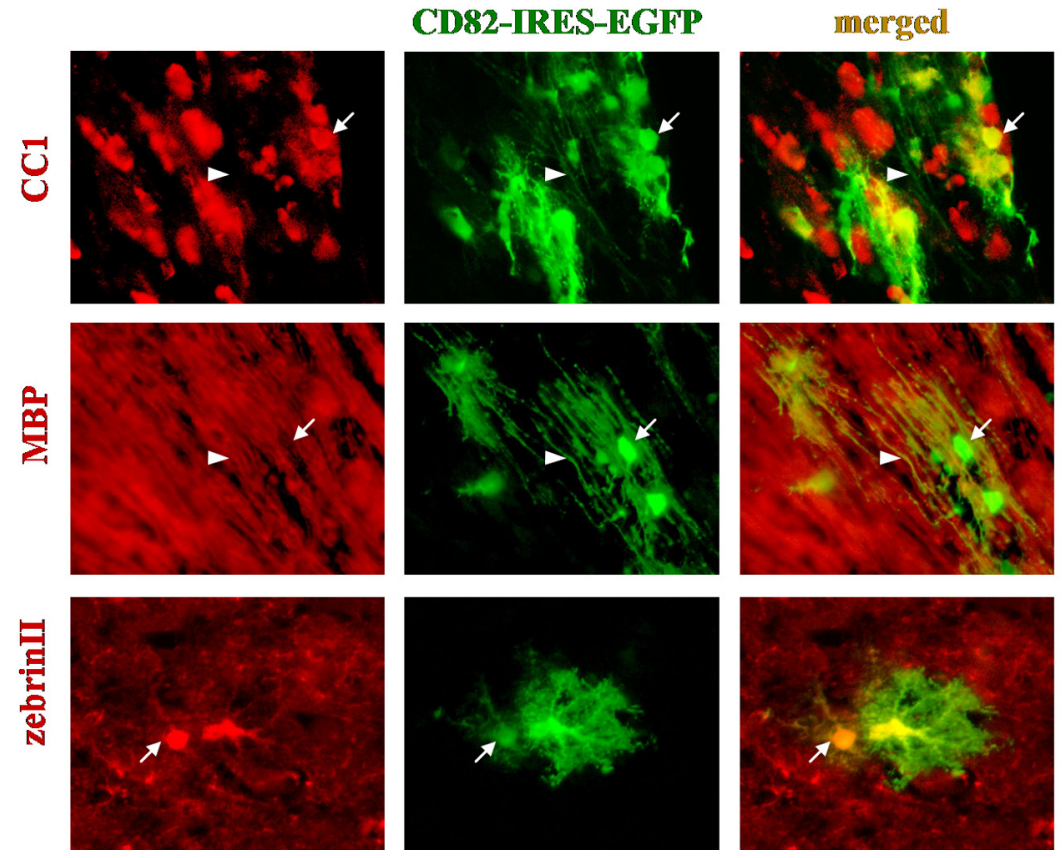

Figure 5. Constitutive expression of $C D 82$ restricts oligodendrocyte progenitor cell migration and promotes myelination. $\boldsymbol{A}, \mathrm{Mi}-$ gration patterns of control EGFP ${ }^{+}$cells and CD82-IRES-EGFP-expressing cells at 7 and 60 dpi into the P2 rat SVZ. B, CD82-IRES$\mathrm{EGFP}^{+}$cells become either myelinating $\mathrm{CC}^{+} / \mathrm{MBP}^{+}$oligodendrocytes in the white matter or zebrinll ${ }^{+}$astrocytes in the cortex. Arrows and arrowheads show typical examples of CD82-IRES-EGFP ${ }^{+}$cell bodies and myelin sheaths, respectively.

\section{Constitutive expression of CD82}

promotes differentiation and restricts migration of oligodendrocyte progenitors in vivo

To analyze the effects of CD82 expression in vivo, we performed stereotactic injections of either the control pQCXIX-IRESEGFP-expressing retrovirus or the pQCXIX-CD82-IRESEGFP-expressing retrovirus into the SVZ of $\mathrm{P} 2$ rats. We examined the dispersion and the marker profiles of the EGFP ${ }^{+}$ cells at different time points after injection (7, 30, 60, and $90 \mathrm{dpi}$ ).

At $7 \mathrm{dpi}$ with the control retrovirus, the majority of the $\mathrm{EGFP}^{+}$cells were located in the subcortical white matter close to the injection site $\left(42.2 \%\right.$ of $\mathrm{EGFP}^{+}$cells). Some cells had migrated into the overlying cortex $(25.2 \%)$ and the striatum (29.6\%), and others had crossed the corpus callosum to the contralateral side $(3 \%)$, whereas some cells were observed in the RMS, consistent with previous results (Kakita et al., 2003; Suzuki and Goldman, 2003) (Fig. 5). In contrast, at 7 dpi, the CD82IRES-EGFP-expressing cells were mainly located in the subcor- tical white matter near the injection site $(84.6 \%$ of the total $\mathrm{EGFP}^{+}$population), and few cells had migrated into the overlying cortex $(15.4 \%)$ (Fig. 5, Table 1). No CD82-IRES-EGFP ${ }^{+}$ cells were observed in the RMS, the striatum, the corpus callosum, or the contralateral side of the brain. At 30, 60, and $90 \mathrm{dpi}$, the CD82-IRES-EGFP ${ }^{+}$cells were exclusively located in the coronal plane of the injection site. Most of them remained in the subcortical white matter close to the SVZ injection site, and few were located in the overlying cortex.

To define the effects of CD82 overexpression on the developmental fates of the infected cells, we performed immunofluorescence for cell lineage markers on cryosections obtained from animals at 7 and 90 dpi. We examined the expression of NG2, CC1, MBP, zebrinII, and GFAP. At 7 dpi, most of the CD82IRES-EGFP $^{+}$cells in the white matter already displayed markers and morphological characteristics of oligodendrocytes. They were all $\mathrm{CCl}^{+}$, whereas at least $70 \%$ were also $\mathrm{MBP}^{+}$myelinat- 
Table 1. Migration patterns of CD82-IRES-EGFP ${ }^{+}$, shRNA-ZsGreen ${ }^{+}$, and control cells at 7 dpi

\begin{tabular}{|c|c|c|c|c|}
\hline Region & CD82-IRES-EGFP ${ }^{+}$ & Control EGFP $^{+}$ & shRNA-ZsGreen ${ }^{+}$ & Control ZsGreen $^{+}$ \\
\hline White matter & $121(84.6 \%)$ & $57(42.2 \%)$ & $50(37.9 \%)$ & $60(40.8 \%)$ \\
\hline Cortex & $22(15.4 \%)$ & $34(25.2 \%)$ & $40(30.3 \%)$ & $39(26.5 \%)$ \\
\hline Striatum & $0(0 \%)$ & $40(29.6 \%)$ & $30(22.7 \%)$ & $42(28.6 \%)$ \\
\hline Corpus callosum & $0(0 \%)$ & $4(3 \%)$ & $12(9.1 \%)$ & $6(4.1 \%)$ \\
\hline Total cells counted & 143 & 135 & 132 & 147 \\
\hline
\end{tabular}

Five representative $40 \times$ fields from three brains were photographed, and green cells were manually counted. There are statistically significant differences between the distributions of CD82-IRES-EGFP ${ }^{+}$and control EGFP ${ }^{+}$cells, shRNA-ZsGreen ${ }^{+}$controlZZsGreen ${ }^{+}$cells, and CD82-IRES-EGFP ${ }^{+}$and shRNA-ZsGreen ${ }^{+}$cells. There is no significant difference between the distributions of control EGFP ${ }^{+}$and control ZsGreen ${ }^{+}$cells. $\left[x_{(\text {CD82-IRES-EGFP }+/ \text { control EGFP }+)}^{2}=4.999 e^{-17}\right.$; $\left.x_{\text {(shRNA-ZSGreen }+/ \text { control ZsGreen }+)}^{2}=0.045 ; x_{\text {(CD82-IRES-EGFP }+ \text { /shRNA-ZzGreen }+)}^{2}=8.078 \mathrm{e}^{-21} ; x_{\text {(control EGPP }+/ \text { control ZsGreen }+)}^{2}=0.931\left(x_{0.05}^{2}=0.352, \mathrm{df}=3\right)\right]$.

Table 2. Immunophenotype of CD82-IRES-EGFP ${ }^{+}$, shRNA-ZsGreen ${ }^{+}$, and control cells at 7 and 90 dpi

\begin{tabular}{|c|c|c|c|c|c|c|c|c|c|}
\hline \multirow[b]{2}{*}{ Region } & \multirow[b]{2}{*}{ Immunophenotype } & \multicolumn{2}{|l|}{ CD82-IRES-EGFP $^{+}$} & \multicolumn{2}{|l|}{ Control EGFP $^{+}$} & \multicolumn{2}{|l|}{ shRNA-ZsGreen $^{+}$} & \multicolumn{2}{|l|}{ Control ZsGreen $^{+}$} \\
\hline & & $7 \mathrm{dpi}$ & $90 \mathrm{dpi}$ & $7 \mathrm{dpi}$ & $90 \mathrm{dpi}$ & $7 \mathrm{dpi}$ & $90 \mathrm{dpi}$ & $7 \mathrm{dpi}$ & $90 \mathrm{dpi}$ \\
\hline \multirow[t]{5}{*}{ White matter } & $\mathrm{CC}^{+}$ & 77 of $79(97.5 \%)$ & 67 of 67 (100\%) & 30 of $68(44.1 \%)$ & 44 of $57(77.2 \%)$ & 13 of $58(22.4 \%)$ & 7 of $57(12.3 \%)$ & 24 of $55(43.6 \%)$ & 38 of $53(71.7 \%)$ \\
\hline & $\mathrm{MBP}^{+}$ & 65 of $87(74.7 \%)$ & 59 of $59(100 \%)$ & 26 of $71(36.6 \%)$ & 41 of $55(74.5 \%)$ & $0(0 \%)$ & $0(0 \%)$ & 19 of $54(35.2 \%)$ & 34 of $51(66.7 \%)$ \\
\hline & $\mathrm{NG} 2^{+}$ & $0(0 \%)$ & $0(0 \%)$ & 25 of $55(45.5 \%)$ & 7 of $51(13.7 \%)$ & 40 of $66(60.6 \%)$ & 53 of $65(81.5 \%)$ & 25 of $56(44.6 \%)$ & 9 of $57(15.8 \%)$ \\
\hline & $\operatorname{PDGFR} \alpha^{+}$ & $0(0 \%)$ & $0(0 \%)$ & 27 of $62(43.5 \%)$ & 6 of $49(12.2 \%)$ & 39 of $67(58.2 \%)$ & 30 of $56(53.6 \%)$ & 26 of $60(43.3 \%)$ & 8 of $56(14.3 \%)$ \\
\hline & olig2 ${ }^{+}$ & $0(0 \%)$ & $0(0 \%)$ & 39 of $67(58.2 \%)$ & 13 of $53(24.5 \%)$ & 44 of $59(74.6 \%)$ & 59 of $68(86.8 \%)$ & 38 of $64(59.4 \%)$ & 16 of $61(26.2 \%)$ \\
\hline \multirow[t]{3}{*}{ Cortex } & $\mathrm{GFAP}^{+}$ & $0(0 \%)$ & 11 of $49(22.4 \%)$ & 12 of $53(22.6 \%)$ & 29 of $45(64.4 \%)$ & 47 of $56(83.9 \%)$ & 67 of $72(93.1 \%)$ & 13 of $55(23.6 \%)$ & 31 of $47(65.6 \%)$ \\
\hline & zebrinll $^{+}$ & 62 of $62(100 \%)$ & 43 of $46(93.5 \%)$ & 29 of $65(44.6 \%)$ & 16 of $47(34.1 \%)$ & $0(0 \%)$ & $0(0 \%)$ & 21 of $48(43.8 \%)$ & 14 of $45(31.1 \%)$ \\
\hline & $\operatorname{PDGFR} \alpha^{+}$ & $0(0 \%)$ & $0(0 \%)$ & 15 of $53(28.3 \%)$ & 6 of $48(12.5 \%)$ & 19 of $54(35.2 \%)$ & 9 of $66(13.6 \%)$ & 16 of $46(34.8 \%)$ & 6 of $42(14.3 \%)$ \\
\hline
\end{tabular}

Five representative $40 \times$ fields from three brains were photographed per marker, and green and double-positive cells were manually counted. The percentage of double-positive cells was calculated by dividing the number of double-positive cells by the total number of green cells counted for each marker, separately. There are statistically significant differences between the distributions of all CD82-IRES-EGFP ${ }^{+} /$marker $^{+}$and control EGFP ${ }^{+} /$marker $^{+}$cells, almost all $^{-}$ shRNA-ZsGreen ${ }^{+} /$marker $^{+}$, and control ZsGreen ${ }^{+} /$marker $^{+}$cells, with the exception of PDGFR $\alpha^{+}$in the cortex. There is no significant difference between the distributions of markers of control EGFP ${ }^{+}$and control ZsGreen ${ }^{+}$cells.

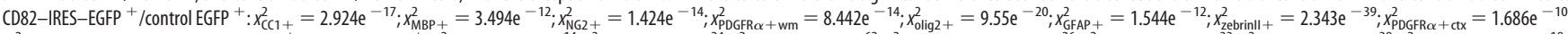
$\left(x_{0.05}^{2}=0.004, \mathrm{df}=1\right)$. shRNA-ZsGreen ${ }^{+} /$control ZsGreen ${ }^{+}: x_{\mathrm{CC} 1+}^{2}=1.212 \mathrm{e}^{-14} ; x_{\mathrm{MBP}+}^{2}=5.84 \mathrm{e}^{-24} ; x_{\mathrm{NG} 2+}^{2}=1.281 \mathrm{e}^{-62} ; x_{\mathrm{PDGFR} \alpha+\text { wm }}^{2}=2.017 \mathrm{e}^{-26} ; x_{\text {olig } 2+}^{2}=3.454 \mathrm{e}^{-33} ; x_{\mathrm{GFAP}+}^{2}=6.765 \mathrm{e}^{-38} ; x_{\text {zebrinll }}^{2}=4.952 \mathrm{e}^{-18} ;$ $x_{\text {PDGFR } \alpha+\mathrm{ctx}}^{2}=0.844\left(x_{0.05}^{2}=0.004, \mathrm{df}=1\right)$. Control EGFP ${ }^{+} /$control ZsGreen $^{+}: x_{\mathrm{CC} 1+}^{2}=0.513 ; x_{\mathrm{MBP}+}^{2}=0.325 ; x_{\mathrm{NG} 2+}^{2}=0.586 ; x_{\mathrm{PDGFR} \alpha+\text { wm }}^{2}=0.578 ; x_{\text {olig } 2+}^{2}=0.714 ; x_{\mathrm{GFAP}+}^{2}=0.799 ; x_{\mathrm{zebrinll}}^{2}=0.581 ; x_{\mathrm{PDGFR} \alpha+\mathrm{Ctx}}^{2}=0.230$ $\left(x_{0.05}^{2}=0.004, \mathrm{df}=1\right)$.

ing oligodendrocytes, displaying the characteristic myelin sheath labeling (Fig. 5, Table 2). None of the CD82-IRES-EGFP ${ }^{+}$cells was $\mathrm{NG}^{+}$or $\mathrm{GFAP}^{+}$, indicating that they had all differentiated to mature oligodendrocytes. In the cortex, CD82-IRES-EGFP ${ }^{+}$ cells were zebrinII ${ }^{+}$yet $\mathrm{GFAP}^{-}$, consistent with either low levels of GFAP in "protoplasmic" cortical astrocytes and/or astrocytes in early stages of differentiation. At 90 dpi, all CD82-IRES$\mathrm{EGFP}^{+}$cells in the white matter were $\mathrm{MBP}^{+}$myelinating oligodendrocytes, whereas in the cortex, cells were zebrinII ${ }^{+}(93.5 \%$ of cortical $\mathrm{EGFP}^{+}$cells) or GFAP ${ }^{+}(22.4 \%)$, displaying the typical bushy, multiprocess morphology of protoplasmic astrocytes.

\section{Downregulation of CD82 prevents progenitor differentiation into myelinating oligodendrocytes in vivo}

To perform downregulation of CD82, we used an shRNA approach. Following the standard guidelines for shRNA design, we chose three $19 \mathrm{nt}$ target sequences in the rat CD82 mRNA. The respective complementary shRNA oligonucleotide strands were designed and annealed. The resulting double-stranded shRNAencoding DNA oligonucleotides (s1, s2, and s3) were cloned into the pSIREN-RetroQ-ZsGreen vector, and shRNA-expressing retroviruses then were generated. To assay the CD82 downregulation efficiency, we infected C6 cells in culture. Three days after infection, the cells were collected and fluorescence-activated cell sorted for ZsGreen (GFP). ZsGreen-shRNA-expressing and nonexpressing (control) C6 cells were replated separately and left in culture for another $3 \mathrm{~d}$ to recover. Total protein and mRNA were then isolated and analyzed for CD82 expression by Western blot and semiquantitative RT-PCR. The results show that all three shRNAs displayed adequate CD82 downregulation efficiency in both mRNA and protein levels. 11 was the most efficient, followed by s2 and s3 (Fig. 6).

To analyze the effects of CD82 downregulation in vivo, we performed stereotactic injections of either the control pSIREN-

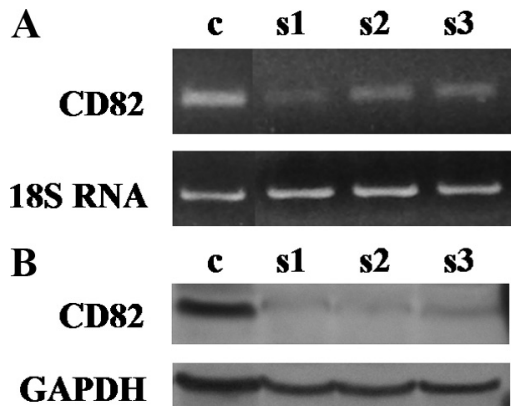

Figure 6. shRNA efficiency assay. Semiquantitative RT-PCR $(\boldsymbol{A})$ and Western blot analysis $(\boldsymbol{B})$ on control uninfected $(6$ cells ( $C$ ) and shRNA-ZsGreen-expressing $(6$ cells $(s 1, s 2, s 3)$. 18S RNA and GAPDH were used as controls.

RetroQ-ZsGreen-expressing retrovirus or a pSIREN-shRNAZsGreen-expressing retrovirus into the SVZ of P2 rats. We used all shRNAs (s1, s2, and s3) to generate retroviruses, performed separate stereotactic injection experiments for each retrovirus, and examined the dispersion and the expression profile of the $\mathrm{ZsGreen}^{+}$cells at different time points after injection (7, 30, 60, and $90 \mathrm{dpi})$.

The effects of the control retrovirus were similar to those of the pQCXIX-IRES-EGFP control used for the CD82 overexpression experiments. At $7 \mathrm{dpi}$, the majority of the $\mathrm{ZsGreen}^{+}$cells were located in the subcortical white matter close to the injection site $(40.8 \%)$. Some cells had migrated into the overlying cortex (26.5\%) and the striatum (28.6\%), and others crossed the corpus callosum to the contralateral side (4.1\%). Some cells were also observed in the RMS. At $7 \mathrm{dpi}$, the s1-ZsGreen ${ }^{+}$and s2$\mathrm{ZsGreen}^{+}$cells were mainly located in the subcortical white matter near the injection site (37.9\%), some had migrated into the corpus callosum $(9.1 \%)$, the striatum $(22.7 \%)$, and the overlying cortex $(30.3 \%)$ (Fig. 7, Table 1), whereas no cells were observed in the RMS. The s3-ZsGreen ${ }^{+}$cells were very few (one to three in 
the coronal plane of the injection site), suggesting an increase in cell death, a common effect of shRNA expression. At 30,60 , and $90 \mathrm{dpi}$, most of the s1-ZsGreen $^{+}$and s2-ZsGreen ${ }^{+}$cells were located in the coronal plane of the injection site. They were located in the subcortical white matter, and some had migrated to the contralateral side through the corpus callosum and others to the cortex and striatum (Fig. 7). s3-ZsGreen ${ }^{+}$cells could not be detected at $30 \mathrm{dpi}$ or thereafter.

To define further the effects of CD82 downregulation on the developmental fates of the infected cells, we performed immunofluorescence for cell lineage markers on cryosections obtained from animals at 7 and 90 dpi. We examined the expression of olig2, NG2, PDGFR $\alpha$, CC1, MBP, zebrinII, and GFAP.

At $7 \mathrm{dpi}$, most of the $\mathrm{s} 1-\mathrm{ZsGreen}{ }^{+}$and s2-ZsGreen ${ }^{+}$cells in the white matter appeared round with few fine processes and expressed markers characteristic for oligodendrocyte progenitors (PDGFR $\alpha^{+}$, olig $2^{+}$, or $\mathrm{NG}_{2}^{+}$), whereas only $22 \%$ were $\mathrm{CC}^{+}{ }^{+}$nonmyelinating oligodendrocytes (Fig. 7, Table 2). In fact, none of the cells resembled myelinating oligodendrocytes, and they were all $\mathrm{MBP}^{-}$. In the cortex, the s1-ZsGreen ${ }^{+}$and s2-ZsGreen ${ }^{+}$cells were mostly GFAP ${ }^{+}(83.9 \%$ of cortical $\mathrm{ZsGreen}^{+}$cells) astrocytes or $\operatorname{PDGFR} \alpha^{+}$, $\mathrm{CCl}^{-}$, round cells with few fine processes. At 90 dpi, most s1-ZsGreen ${ }^{+}$and s2$\mathrm{ZsGreen}^{+}$cells in the white matter remained immature, PDGFR $\alpha^{+}$, olig ${ }^{+}$, or $\mathrm{NG}^{+}$, and few $\mathrm{CCl}^{+}$(12.3\%) nonmyelinating oligodendrocytes. In the cortex, almost all s1-ZsGreen ${ }^{+}$and s2-ZsGreen ${ }^{+}$ cells were $\mathrm{GFAP}^{+}$astrocytes.

\section{Discussion}

CD82 is expressed in oligodendrocytes and $\mathrm{O}_{4}^{+}$cells in the adult brain In the oligodendrocyte lineage, CD82 appears to be expressed in advanced stages of development. CD82 expression appears to begin beyond the $\mathrm{NG}^{+}{ }^{+}$stage, overlapping to some extent with olig2 and with CC1, O4, and O1 markers (Fig. 8). This developmental localization is consistent with our gene chip observations that adult $\mathrm{O}_{4}{ }^{+}$cells, which are $\mathrm{NG}_{2}{ }^{-}$, express transcripts for later oligodendrocyte and myelin genes, such as mag, mog, $m b p$, plp, carbonic anhydrase, and $\alpha B$-crystallin (Lin et al., 2009). The observed differences between adult and neonatal $\mathrm{O}_{4}^{+}$cells concerning both their response to growth factors in culture and the expression of several genes suggest that the adult $\mathrm{O}_{4}{ }^{+}$cells are at a more mature state or at least that the adult $\mathrm{O}_{4}{ }^{+}$cells are a mixed population consisting of oligodendrocytes at various premyelinating stages of differentiation. In any case, the adult $\mathrm{O} 4{ }^{+}$cells that we isolate are $\mathrm{NG} 2^{-}$, mostly PDGFR $\alpha^{-}$(Mason

A

B 7 dpi 60 dpi
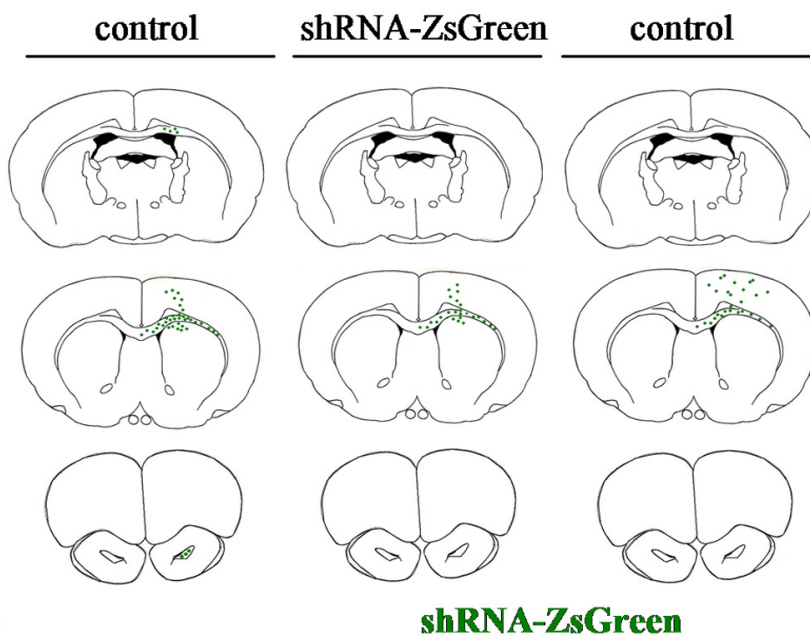

shRNA-ZsGreen
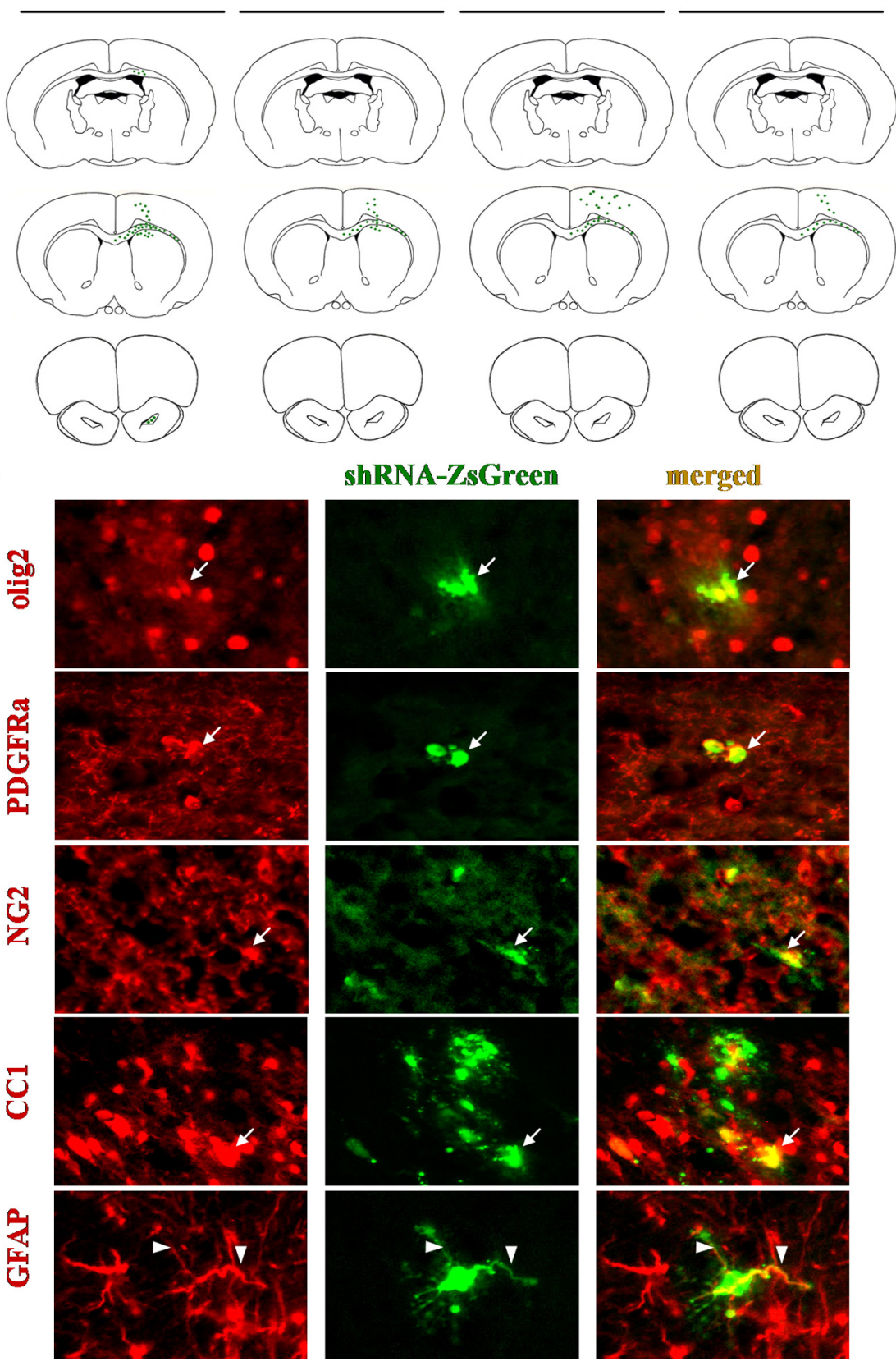

Figure 7. CD82 downregulation prevents oligodendrocyte progenitor cell differentiation and myelination. $A$, Migration patterns of control EGFP ${ }^{+}$cells and shRNA-ZsGreen-expressing cells at 7 and 60 dpi into the P2 rat SVZ. B, shRNA-ZsGreen ${ }^{+}$cells remain immature olig2 ${ }^{+}, \mathrm{PDGFR}^{+}{ }^{+}, \mathrm{NG2}{ }^{+}$oligodendrocyte progenitor cells or become $\mathrm{CC}^{+}{ }^{+}$nonmyelinating oligodendrocytes in the white matter or GFAP ${ }^{+}$astrocytes in the cortex. Arrows and arrowheads show typical examples of cell bodies and processes of shRNA-ZsGreen-expressing cells.

and Goldman, 2002) and CD82 ${ }^{+}$, an immunophenotype consistent with our observation that $\mathrm{CD} 82^{+}$cells in the adult rat brain sections are also $\mathrm{NG}^{-}$.

Constitutive CD82 expression restricts progenitor migration and promotes myelination, although its downregulation prevents progenitor differentiation and myelination We found that the constitutive and premature expression of CD82 in postnatal SVZ cells in vivo substantially restricted the migration of oligodendrocyte lineage cells and apparently pro- 


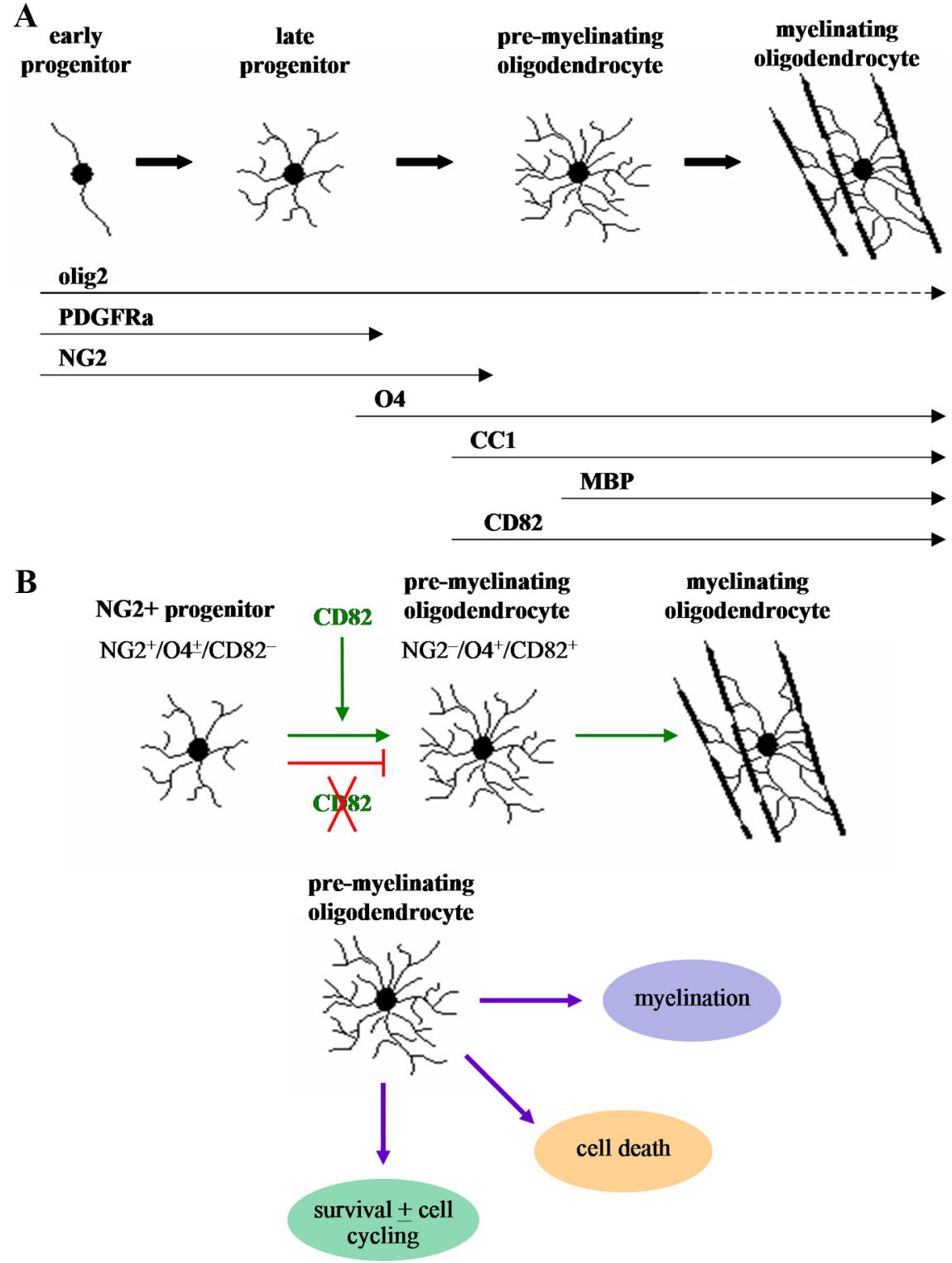

Figure 8. Schematic representation of CD82 expression during oligodendrocyte development. $A, C D 82$ is expressed beyond the $\mathrm{NG2}^{+}$stage, overlapping with olig2, CC1, 04, 01, and myelination. $\boldsymbol{B}, \mathrm{CD} 82$ is required for myelination, although its loss of expression prevents the differentiation of $\mathrm{NG}^{+}$cells into $\mathrm{NG}^{-} / \mathrm{CD} 82^{+}$premyelinating oligodendrocytes. Premyelinating oligodendrocytes and progenitors that do not progress into myelination either remain as cycling cells or die.

crossed the corpus callosum at 7 dpi was in fact higher than that of the control GFP-expressing cells, although the percentages are small in both cases. shRNA$\mathrm{ZsGreen}^{+}$cells in the white matter were mostly immature and resembled oligodendrocyte progenitors $\left(\mathrm{NG} 2^{+}\right.$, olig $2^{+}$, $\left.\operatorname{PDGFR} \alpha^{+}, \mathrm{CC}^{-}, \mathrm{MBP}^{-}\right)$, and some were $\mathrm{CCl}^{+}, \mathrm{MBP}^{-}$, nonmyelinating oligodendrocytes. In the cortex, most shRNA-ZsGreen ${ }^{+}$cells were GFAP $^{+}$ astrocytes.

The lack of CD82 expression in the $\mathrm{NG}_{2}{ }^{+}$population of the developing and adult CNS, the partial overlap with olig2, and the substantial overlap with CC1 suggest that CD82 accumulates late in the oligodendrocyte lineage. Oligodendrocyte progenitors are thought to pass through an obligatory $\mathrm{NG}_{2}{ }^{+}$stage, after which those that differentiate into myelinating oligodendrocytes lose NG2. Some oligodendrocyte lineage cells do not myelinate; of these, the largest number retain $\mathrm{NG}_{2}{ }^{+}$ expression and appear as lacy, multibranched cells, termed "polydendrocytes" (Nishiyama, 2007; Nishiyama et al., 2009). Recent studies have focused on their responses to demyelination (Keirstead et al., 1998; Reynolds et al., 2002), their interactions with neurons (Bergles et al., 2000; Paukert and Bergles, 2006), and their potential to generate protoplasmic astrocytes during development (Zhu et al., 2008). Other nonmyelinating oligodendrocyte lineage cells appear to be further advanced on the developmental spectrum, such as the $\mathrm{O}^{+} / \mathrm{NG}^{-}$cells isolated from the adult brain (Mason and Goldman, 2002).

The transition of $\mathrm{NG}^{+} / \mathrm{CD} 82^{-}$cells to $\mathrm{NG}^{-} / \mathrm{CD} 82^{+}$oligodendrocytes may be a key developmental step in myelination and in remyelination (Fig. 8). Whether CD82 expression is necessary and sufficient to induce this transition re-

moted myelination, the latter function judged by the very high proportion of oligodendrocyte lineage cells that appeared mature and myelinating. In contrast, SVZ cells labeled with control retroviruses migrate extensively and do not all differentiate into myelinating oligodendrocytes over this time frame (this study, and Levison et al., 1993; Zerlin et al., 2004). We do not know yet whether the effects on migration and myelination are independent or linked. The development of astrocytes from SVZ cells was apparently not affected, because we found many zebrinII ${ }^{+}$labeled astrocytes in the cortex.

Preventing the expression of CD82 by SVZ cells with shRNAexpressing retroviruses prevented their differentiation into myelinating oligodendrocytes, suggesting that CD82 expression is in some way required for myelination. The migration of the shRNA-ZsGreen ${ }^{+}$cells followed a pattern similar to that of control virus infected cells. Thus, a lack of CD82 did not impede cell migration. The percentage of shRNA-expressing cells that mains to be determined. From the literature on CD82 expression in carcinomas (see below), one might expect the molecule to play a role in the cessation of progenitor migration. However, the multibranched $\mathrm{NG}_{2}{ }^{+} / \mathrm{CD} 82^{-}$cells of the adult CNS have presumably stopped migrating or at least do not migrate as extensively as early oligodendrocyte progenitors. CD82 could also regulate late-stage oligodendrocyte differentiation and/or proliferative rate.

In contrast to the presence of CD82 in oligodendrocyte lineage cells, we found no detectable CD82 in cells of the RMS or in neurons in the young or adult brain, indicating that neuroblasts and mature neurons do not require this protein. However, when we overexpressed CD82 or shRNA for CD82 in SVZ cells, we saw few labeled cells in the RMS. The retrovirus-infectable cells of the SVZ are a mixture of immature neurons and immature glia, and the retrovirus injections label both neurons and glia (Suzuki and Goldman, 2003). We do not know why we find few labeled cells in 
the RMS, although we might speculate that both the protein itself and the shRNA could be toxic to neuroblasts. In fact, cell death is a common effect of shRNA expression, a result we observed in one of three CD82-specific sequences. However, in this report, we focused on glial rather than on neuronal development.

\section{How might CD82 regulate oligodendrocyte progenitor migration and/or differentiation?}

Studies in non-CNS tissues have shed some light on CD82 function in cell migration and differentiation. CD82 forms complexes with a wide range of transmembrane proteins, such as other tetraspanins, integrins, and growth factor receptors, such as EGFR and c-Met, as well as with lipid rafts (Odintsova et al., 2003; Delaguillaumie et al., 2004). The CD82/c-Met complex inhibits hepatocyte growth factor (HGF)-induced lung cancer cell migration by inactivating Rho GTPases through Ras-Cdc42/Rac and Pi3k/Cdc42/Rac pathways (Takahashi et al., 2007). In another study, CD82 and GM2 ganglioside were found to form a complex that inhibited HGF-induced c-Met tyrosine kinase activity in bladder cancer cells (Todeschini et al., 2007).

Several growth factors, including PDGF, EGF, HGF, basic FGF, and IGF-1, regulate progenitor proliferation, migration, and differentiation. In particular, HGF promotes oligodendrocyte progenitor proliferation and attenuates their differentiation into oligodendrocytes (Ohya et al., 2007). The HGF receptor c-Met is present in both progenitors and oligodendrocytes, at least in vitro (Yan and Rivkees, 2002). Interestingly, HGF secreted by TGF- $\beta$-treated microglia acts as a chemoattractant for progenitors in vitro, whereas experimental autoimmune encephalomyelitis spinal cord lesions contain both progenitors and HGF-expressing macrophages only in the recovery phase, suggesting a possible role for $\mathrm{HGF}$ as a chemotactic factor to achieve accumulation and proliferation of progenitors in demyelinating/remyelinating lesions (Lalive et al., 2005). Furthermore, Rho GTPases, molecules downstream of the HGF/c-Met pathway, play significant roles in oligodendrocyte development by promoting progenitor migration when activated, whereas their inactivation is a critical factor to initiate myelination (Liang et al., 2004; Mi et al., 2005; Kippert et al., 2007). Whether the expression of CD82 in oligodendrocyte progenitors inhibits their migration, proliferation, or differentiation by inhibiting HGF/c-Met or other growth factor receptor pathways remains to be determined.

Oligodendrocyte progenitor proliferation and survival is dependent in part on growth factor and integrin signaling. Signaling through these molecules is in turn regulated by their associations with lipid rafts (Baron et al., 2003; Decker and ffrench-Constant, 2004). Because tetraspanins are components of lipid rafts, a change in raft composition by the inclusion of CD82, for example, could have important effects on signaling pathways underlying oligodendrocyte development.

Tetraspanins Tspan2, CD9, CD81, and OAP1/Tspan3 (OSP/ claudin11-associated protein) are expressed during oligodendrocyte development. Tspan2 is specifically expressed by oligodendrocytes, although it is not clear at what stage of development it is present (Birling et al., 1999). One study reported that CD9 is present in oligodendrocytes during the final stages of myelination (Kagawa et al., 1997). Another study suggested that CD9 is expressed somewhat earlier, during the late $\mathrm{NG}^{+}{ }^{+}$stage, and interacts with CD81, Tspan2, and $\beta 1$ integrin (Terada et al., 2002). CD9-deficient mice myelinate normally, indicating that its presence is not a requirement for oligodendrogenesis and myelination, however, or that other tetraspanins compensate in the knock-out (Terada et al., 2002). In the PNS, CD9 can be impor- tant in the formation of paranodal junctions and myelination (Ishibashi et al., 2004). CD9 does not appear to be specific to oligodendrocytes, being found in astrocytes and microglia, at least in culture (Terada et al., 2002). OAP1/Tspan3 forms a complex with OSP/claudin 11 (oligodendrocyte-specific protein) and $\beta 1$ integrin that appears to be involved in oligodendrocyte proliferation and migration (Tiwari-Woodruff et al., 2001, 2004). In contrast to CD9 and CD81, OAP is expressed at all stages of oligodendrocyte development but is also expressed in astrocytes (Tiwari-Woodruff et al., 2004). CD81 is expressed in myelin, but it is also studied in microglia and reactive astrocytes (Dijkstra et al., 2001; Geisert et al., 2002).

In contrast to other tetraspanins, CD82 appears to be oligodendrocyte specific in the CNS, to be expressed at a post-NG2 ${ }^{+}$ stage and through myelination. The stage of appearance of CD82 and the functional studies presented in this manuscript suggest that CD82 plays some key function in the transition of nonmyelinating to myelinating oligodendrocytes. Additional studies of interactions between CD82 and other molecules could illuminate the mechanisms by which it restricts progenitor migration and promotes myelination. Furthermore, the expression of different tetraspanins at different stages of oligodendrocyte development suggests that each regulates stage-appropriate cell-cell interactions and growth factor responses.

\section{References}

Baron W, Decker L, Colognato H, ffrench-Constant C (2003) Regulation of integrin growth factor interactions in oligodendrocytes by lipid raft microdomains. Curr Biol 13:151-155.

Bergles DE, Roberts JD, Somogyi P, Jahr CE (2000) Glutamatergic synapses on oligodendrocyte precursor cells in the hippocampus. Nature 405:187-191.

Birling MC, Tait S, Hardy RJ, Brophy PJ (1999) A novel rat tetraspan protein in cells of the oligodendrocyte lineage. J Neurochem 73:2600-2608.

Bottenstein JE, Sato GH (1979) Growth of a rat neuroblastoma cell line in serum-free supplemental medium. Proc Natl Acad Sci U S A 76:514-517.

Decker L, ffrench-Constant C (2004) Lipid rafts and integrin activation regulate oligodendrocyte survival. J Neurosci 24:3816-3825.

Delaguillaumie A, Lagaudrière-Gesbert C, Popoff MR, Conjeaud H (2002) Rho GTPases link cytoskeletal rearrangements and activation processes induced via the tetraspanin CD82 in T lymphocytes. J Cell Sci 115:433-443.

Delaguillaumie A, Harriague J, Kohanna S, Bismuth G, Rubinstein E, Seigneuret M, Conjeaud H (2004) Tetraspanin CD82 controls the association of cholesterol-dependent microdomains with the actin cytoskeleton in $\mathrm{T}$ lymphocytes: relevance to co-stimulation. J Cell Sci 117:5269-5282.

Dijkstra S, Geisert EE Jr, Dijkstra CD, Bär PR, Joosten EA (2001) CD81 and microglial activation in vitro: proliferation, phagocytosis and nitric oxide production. J Neuroimmunol 114:151-159.

Dong JT, Lamb PW, Rinker-Schaeffer CW, Vukanovic J, Ichikawa T, Isaacs JT, Barrett JC (1995) KAI1, a metastasis suppressor gene for prostate cancer on human chromosome 11p11.2. Science 268:884-886.

Gard AL, Pfeiffer SE (1990) Two proliferative stages of the oligodendrocyte lineage (A2B5+O4- and $\mathrm{O} 4+\mathrm{GalC}-$ ) under different mitogenic control. Neuron 5:615-625.

Geisert EE Jr, Williams RW, Geisert GR, Fan L, Asbury AM, Maecker HT, Deng J, Levy S (2002) Increased brain size and glial cell number in CD81-null mice. J Comp Neurol 453:22-32.

Gensert JM, Goldman JE (1997) Endogenous progenitors remyelinate demyelinated axons in the adult CNS. Neuron 19:197-203.

Gensert JM, Goldman JE (2001) Heterogeneity of cycling glial progenitors in the adult mammalian cortex and white matter. J Neurobiol 48:75-86.

Ishibashi T, Ding L, Ikenaka K, Inoue Y, Miyado K, Mekada E, Baba H (2004) Tetraspanin protein CD9 is a novel paranodal component regulating paranodal junctional formation. J Neurosci 24:96-102.

Jackson P, Marreiros A, Russell PJ (2005) KAI1 tetraspanin and metastasis suppressor. Int J Biochem Cell Biol 37:530-534.

Kagawa T, Mekada E, Shishido Y, Ikenaka K (1997) Immune system-related 
CD9 is expressed in mouse central nervous system myelin at a very late stage of myelination. J Neurosci Res 50:312-320.

Kakita A, Goldman JE (1999) Patterns and dynamics of SVZ cell migration in the postnatal forebrain: monitoring living progenitors in slice preparations. Neuron 23:461-472.

Kakita A, Zerlin M, Takahashi H, Goldman JE (2003) Some glial progenitors in the neonatal subventricular zone migrate through the corpus callosum to the contralateral cerebral hemisphere. J Comp Neurol 458:381-388.

Keirstead HS, Levine JM, Blakemore WF (1998) Response of the oligodendrocyte progenitor cell population (defined by NG2 labelling) to demyelination of the adult spinal cord. Glia 22:161-170.

Kippert A, Trajkovic K, Rajendran L, Ries J, Simons M (2007) Rho regulates membrane transport in the endocytic pathway to control plasma membrane specialization in oligodendroglial cells. J Neurosci 27:3560-3570.

Lagaudrière-Gesbert C, Lebel-Binay S, Hubeau C, Fradelizi D, Conjeaud H (1998) Signaling through the tetraspanin CD82 triggers its association with the cytoskeleton leading to sustained morphological changes and $\mathrm{T}$ cell activation. Eur J Immunol 28:4332-4344.

Lalive PH, Paglinawan R, Biollaz G, Kappos EA, Leone DP, Malipiero U, Relvas JB, Moransard M, Suter T, Fontana A (2005) TGF-beta-treated microglia induce oligodendrocyte precursor cell chemotaxis through the HGF-c-Met pathway. Eur J Immunol 35:727-737.

Levison SW, Chuang C, Abramson BJ, Goldman JE (1993) The migrational patterns and developmental fates of glial precursors in the rat subventricular zone are temporally regulated. Development 119:611-622.

Liang X, Draghi NA, Resh MD (2004) Signaling from integrins to Fyn to Rho family GTPases regulates morphologic differentiation of oligodendrocytes. J Neurosci 24:7140-7149.

Lin G, Mela A, Guilfoyle EM, Goldman JE (2009) Neonatal and adult O4+ oligodendrocyte lineage cells display different growth factor responses and different gene expression patterns. J Neurosci Res. Advance online publication. Retrieved April 9, 2009. doi:10.1002/jnr.22065.

Liu WM, Zhang XA (2006) KAI1/CD82, a tumor metastasis suppressor. Cancer Lett 240:183-194.

Mason JL, Goldman JE (2002) A2B5+ and O4+ cycling progenitors in the adult forebrain white matter respond differentially to PDGF-AA, FGF-2 and IGF-1. Mol Cell Neurosci 20:30-42.

Mason JL, Toews A, Hostettler JD, Morell P, Suzuki K, Goldman JE, Matsushima GK (2004) Oligodendrocytes and progenitors become progressively depleted within chronically demyelinated lesions. Am J Pathol 164:1673-1682.

Mi S, Miller RH, Lee X, Scott ML, Shulag-Morskaya S, Shao Z, Chang J, Thill G, Levesque M, Zhang M, Hession C, Sah D, Trapp B, He Z, Jung V, McCoy JM, Pepinsky RB (2005) LINGO-1 negatively regulates myelination by oligodendrocytes. Nat Neurosci 8:745-751.

Nishiyama A (2007) Polydendrocytes: NG2 cells with many roles in development and repair of the CNS. Neuroscientist 13:62-76.

Nishiyama A, Komitova M, Suzuki R, Zhu X (2009) Polydendrocytes (NG2 cells): multifunctional cells with lineage plasticity. Nat Rev Neurosci 10:9-22.

Odintsova E, Voortman J, Gilbert E, Berditchevski F (2003) Tetraspanin CD82 regulates compartmentalisation and ligand-induced dimerization of EGFR. J Cell Sci 116:4557-4566.

Ohya W, Funakoshi H, Kurosawa T, Nakamura T (2007) Hepatocyte growth factor (HGF) promotes oligodendrocyte progenitor cell proliferation and inhibits its differentiation during postnatal development in the rat. Brain Res 1147:51-65.
Ono M, Handa K, Withers DA, Hakomori SI (1999) Motility inhibition and apoptosis are induced by metastasis-suppressing gene product CD82 and its analogue CD9, with concurrent glycosylation. Cancer Res 59:2335-2339.

Paukert M, Bergles DE (2006) Synaptic communication between neurons and NG2+ cells. Curr Opin Neurobiol 16:515-521.

Reynolds R, Dawson M, Papadopoulos D, Polito A, Di Bello IC, Pham-Dinh D, Levine J (2002) The response of NG2-expressing oligodendrocyte progenitors to demyelination in MOG-EAE and MS. J Neurocytol 31:523-536.

Shibagaki N, Hanada K, Yamaguchi S, Yamashita H, Shimada S, Hamada H (1998) Functional analysis of CD82 in the early phase of T cell activation: roles in cell adhesion and signal transduction. Eur J Immunol 28:1125-1133.

Shibagaki N, Hanada K, Yamashita H, Shimada S, Hamada H (1999) Overexpression of CD82 on human T cells enhances LFA-1/ICAM-1-mediated cell-cell adhesion: functional association between CD82 and LFA-1 in T cell activation. Eur J Immunol 29:4081-4091.

Sommer I, Schachner M (1981) Monoclonal antibodies (O1 to O4) to oligodendrocyte cell surfaces: an immunological study in the central nervous system. Dev Biol 83:311-327.

Staugaitis SM, Zerlin M, Hawkes R, Levine JM, Goldman JE (2001) Aldolase $\mathrm{C} /$ Zebrin II expression in the neonatal rat forebrain reveals cellular heterogeneity within the subventricular zone and early astrocyte differentiation. J Neurosci 21:6195-6205.

Suzuki SO, Goldman JE (2003) Multiple cell populations in the early postnatal subventricular zone take distinct migratory pathways: a dynamic study of glial and neuronal progenitor migration. J Neurosci 23:4240-4250.

Takahashi M, Sugiura T, Abe M, Ishii K, Shirasuna K (2007) Regulation of c-Met signaling by the tetraspanin KAI-1/CD82 affects cancer cell migration. Int J Cancer 121:1919-1929.

Terada N, Baracskay K, Kinter M, Melrose S, Brophy PJ, Boucheix C, Bjartmar C, Kidd G, Trapp BD (2002) The tetraspanin protein, CD9, is expressed by progenitor cells committed to oligodendrogenesis and is linked to betal integrin, CD81 and Tspan-2. Glia 40:350-359.

Tiwari-Woodruff SK, Buznikov AG, Vu TQ, Micevych PE, Chen K, Kornblum HI, Bronstein JM (2001) OSP/claudin-11 forms a complex with a novel member of the tetraspanin super family and betal integrin and regulates proliferation and migration of oligodendrocytes. J Cell Biol 153:295-305.

Tiwari-Woodruff SK, Kaplan R, Kornblum HI, Bronstein JM (2004) Developmental expression of OAP-1/Tspan-3, a member of the tetraspanin superfamily. J Neurosci Res 77:166-173.

Todeschini AR, Dos Santos JN, Handa K, Hakomori SI (2007) Ganglioside GM2-tetraspanin CD82 complex inhibits Met and its cross-talk with integrins, providing a basis for control of cell motility through glycosynapse. J Biol Chem 282:8123-8133.

Yan H, Rivkees SA (2002) Hepatocyte growth factor stimulates the proliferation and migration of oligodendrocyte precursor cells. J Neurosci Res 69:597-606.

Yang X, Wei LL, Tang C, Slack R, Mueller S, Lippman ME (2001) Overexpression of KAI1 suppresses in vitro invasiveness and in vivo metastasis in breast cancer cells. Cancer Res 61:5284-5288.

Zerlin M, Milosevic A, Goldman JE (2004) Glial progenitors of the neonatal subventricular zone differentiate asynchronously, leading to spatial dispersion of glial clones and to the persistence of immature glia in the adult mammalian CNS. Dev Biol 270:200-213.

Zhu X, Bergles DE, Nishiyama A (2008) NG2 cells generate both oligodendrocytes and gray matter astrocytes. Development 135:145-157. 